\title{
PLEUROZIA POCSII SP. NOV. (PLEUROZIACEAE) FROM NEW CALEDONIA
}

\author{
FRANK MÜLLER
}

\begin{abstract}
A new species, Pleurozia pocsii (Pleuroziaceae) from New Caledonia, is described and illustrated. The species belongs in subgenus Diversifolia B. M. Thiers. Pleurozia pocsii is easily distinguished from the other species of the genus by the laciniate dorsal and ventral leaf lobe apices of the explanate-lobuled leaves, the laciniate bracts of the sterile gynoecia, and the strongly bulging cells at the apex of the dorsal lobules of the saccate-lobuled leaves.
\end{abstract}

Key words: Hepaticae, South Pacific, biodiversity, Pleurozia, New Caledonia

Frank Müller, Technische Universität Dresden, Institut für Botanik, D-01062 Dresden, Germany; e-mail: Frank.Mueller@ tu-dresden.de

\section{INTRODUCTION}

The genus Pleurozia Dum. is the only member of the monotypic family Pleuroziaceae. The family was traditionally placed in subclass Jungermanniidae of the hepaticae (He-Nygrén et al. 2006), but in a more recent treatment, it was transferred to subclass Metzgeriidae (Crandall-Stotler et al. 2009).

Pleurozia is a very distinctive genus. Many of the species are large, conspicuous, and strongly pigmented, with deeply concave, usually bilobed leaves. Species in which the dorsal lobe of the bilobed leaf is developed into a complex water sac that includes a complicated aperture mechanism are especially distinctive.

A unique feature of Pleurozia is the growth of the stem by means of a 2-sided apical cell (Crandall-Stotler 1976); it is 3-sided in all other genera of leafy liverworts. Another characteristic is the production of two types of gynoecia: those that produce archegonia (fertile gynoecia) and those that appear never to produce archegonia (sterile gynoecia). Sterile gynoecia are not found in all species, but when present, they are clearly differentiated from the fertile gynoecia. Fertile perianths are plicate, with a ciliate mouth, whereas sterile perianths are terete (smooth), often abruptly con- stricted at the narrow or broad apex, and have an entire mouth (Thiers 1993).

The genus, revised taxonomically by Thiers (1993), included eleven species. All have very local or disjunct distributions, and most are restricted to montane habitats in the tropics and subtropics, where they grow as epiphytes in forests in humid environments. Some species are known from other habitats, including P. purpurea Lindb., a species of bogs and other wet habitats in coastal areas in West and northern Europe, western North America and East Asia, and also at high elevations in the Himalayan region (Thiers 1993). Pleurozia conchifolia (Hook. \& Arnott) Austin may also be found in bogs, and a few species grow on wet rock ledges $[P$. gigantea (F. Weber) Lindb., P. heterophylla Steph. ex Fulford and P. paradoxa (J. B. Jack) Schiffn.].

New Caledonia is a centre of diversity for the genus, with four species known: $P$. articulata (Lindb.) Lindb. \& Lackström (also known from Australia [Queensland]), P. caledonica (J. B. Jack) Steph. (endemic to New Caledonia), P. curiosa B. M. Thiers (endemic to New Caledonia), and P. gigantea (known from Africa, Asia, Australasia, and tropical Pacific islands). 
The author made collections of Pleurozia during two expeditions to New Caledonia in 2001 and 2003. Among these collections an undescribed species was found.

\section{DESCRIPTION}

\section{Pleurozia pocsii Frank Müll., sp. nov.}

Figs $1 \& 2$

Pleurozia pocsii differs from all other known Pleurozia species in the (i) laciniate dorsal and ventral leaf lobe apices of the explanate-lobuled leaves, (ii) laciniate apices of the bracts of the sterile gynoecia, and (iii) strongly bulging cells at the apex of the dorsal lobules of saccate-lobuled leaves.

TYPE: NEW CALEDONIA, Noumea $45 \mathrm{~km} \mathrm{~N}$ : Mont Humboldt, ascension from the mountain shelter below the top to the top of the mountain, epiphytic, c. $1500 \mathrm{~m}, 21^{\circ} 53^{\prime} \mathrm{S}, 166^{\circ} 25^{\prime} \mathrm{E}, 31$ Aug. 2003, F. Müller NC708 (HOLOTYPE: DR).

Plants to $2.5 \mathrm{~cm}$ long, $0.75-1.5 \mathrm{~mm}$ wide, forming dense tufts, red brown in color, laciniate leaf teeth white; stems 350-550 $\mu \mathrm{m}$ diam., epidermis not strongly differentiated, medulla 8-10 cells wide, walls with large confluent trigones. Simple leaves restricted to branch bases, ovateligulate, $0.4-1.1 \times 0.4-1.0 \mathrm{~mm}$, concave, margins entire, notched at apex or simple, bases cordate. Explanate-lobuled leaves dominant on main and secondary branches above base, bilobed to 0.65-0.75 leaf length; ventral lobes ovate, 1.5$2.3 \times 0.7-1.4 \mathrm{~mm}$, acumen with $4-12$ laciniate teeth of (3-)5-10 uniseriate elongate cells, teeth 200-800(-1200) $\mu \mathrm{m}$ long, outer margin often with scattered laciniate teeth, base cordate, cells of leaf apex isodiametric, 35-55(-65) $\mu \mathrm{m}$ diam., with strongly bulging trigones, cells at mid-leaf and at leaf base rectangular, 40-80 × 22-32 $\mu \mathrm{m}$; dorsal lobules narrowly ligulate to ovate, concave, $1.5-2.0 \times 0.4-0.6 \mathrm{~mm}$, attachment to ventral lobe extending 410-640 $\mu \mathrm{m}$, basal flaps free, rectangular, 600-800 × 200-370 $\mu \mathrm{m}$. Saccate-lobuled leaves rare to frequent at the top of sterile secondary branches and innovations (= branches without perianths); ventral lobes ovate, 0.6-0.8 $\times 0.4-0.6 \mathrm{~mm}$, concave, apex bilobed to $0.2-0.3$ leaf length, sinus V-shaped, lobules narrowly to broadly acute, margins entire; cells similar in size and shape to those of ventral lobes of explanatelobuled leaves; dorsal lobules obovate, 0.6-0.8 $\times 0.4-0.6 \mathrm{~mm}$, apex with strongly bulging cells, attachment to ventral lobe extending $330 \mu \mathrm{m}$, aperture complex acinosa-type (subapical, basin oblong, lip discontinuous, overarching basin on the proximal side).

Probably dioicous. Androecia not seen. Fertile gynoecia on short branches; bracts 2.5-3.2 $\times 3.0-4.0 \mathrm{~mm}$, trilobed, lobes triangular, acute, laciniate, extending $c a 0.5$ bract length, each lobe at the acumen and the margins below apices with 4-10(-12) laciniate teeth of 5-7 uniseriate elongate cells, teeth $280-700(-1200) \mu \mathrm{m}$ long; fertile perianths 5.5-6.5 × 1.3-2.0 mm, tapering from near base to a small mouth, deeply plicate for almost entire length, mouth ciliate, the cilia 4-10 cells long, with sparse articulations or branches, cells elongate; the upper part of the perianth keels of the plications with short cilia 3-7 cells long.

Sterile gynoecia on short branches, bracts 1.8-2.5 $\times 2.5-3.5 \mathrm{~mm}$, trilobed, lobes triangular, acute, laciniate, extending $c a 0.6$ bract length, each lobe at the acumen with 3-8 laciniate teeth of 5-7 uniseriate elongate cells, teeth $280-500 \mu \mathrm{m}$ long, margins below apices with a few scattered teeth; sterile perianths cylindrical or clavate, $2.0-3.5 \times$ 0.75-1.0 mm, mouth entire.

ADDITIONAL MATERIAL SEEN: NEW CALEDONIA, Noumea $45 \mathrm{~km} \mathrm{~N}$ : Mont Humboldt, ascension from the mountain shelter below the top to the top of the mountain, epiphytic, c. $1550 \mathrm{~m}, 21^{\circ} 53^{\prime} \mathrm{S}, 166^{\circ} 25^{\prime} \mathrm{E}, 31 \mathrm{Aug}$. 2003, F. Müller NC709 (DR).

ECOlOGY AND DISTRIBUTION. Pleurozia pocsii grows epiphytically in montane rainforests at 1500-1550 m. Pleurozia caledonica (J. B. Jack) Steph. was found occurring intermixed with the species at one site. Pleurozia pocsii is apparently rare, and currently known only from the type locality.

ETYMOLOGY. The new species is named in honour of Tamás Pócs, eminent bryologist and ecologist, on the occasion of his $80^{\text {th }}$ birthday. 

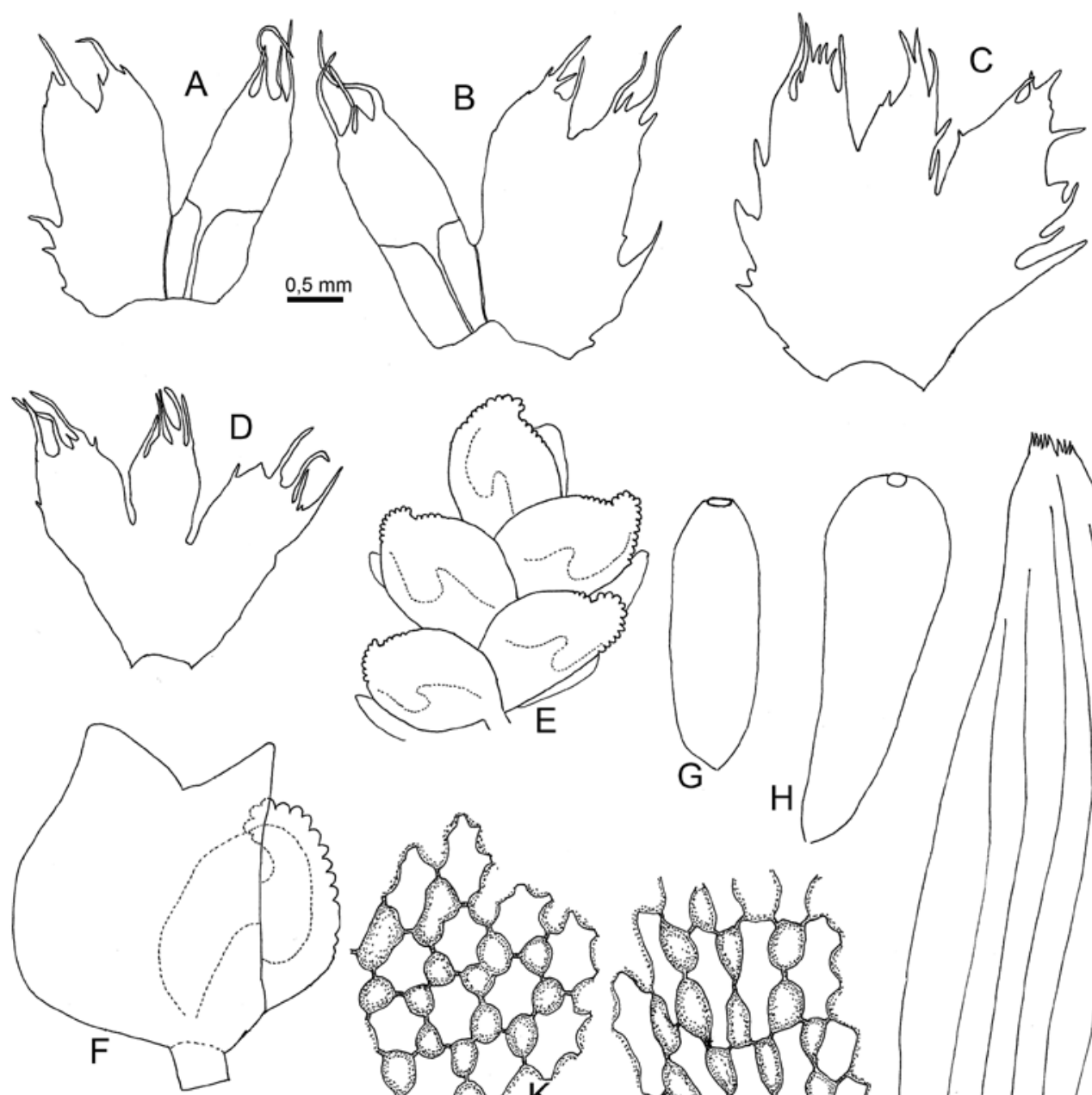

$200 \mu \mathrm{m}$
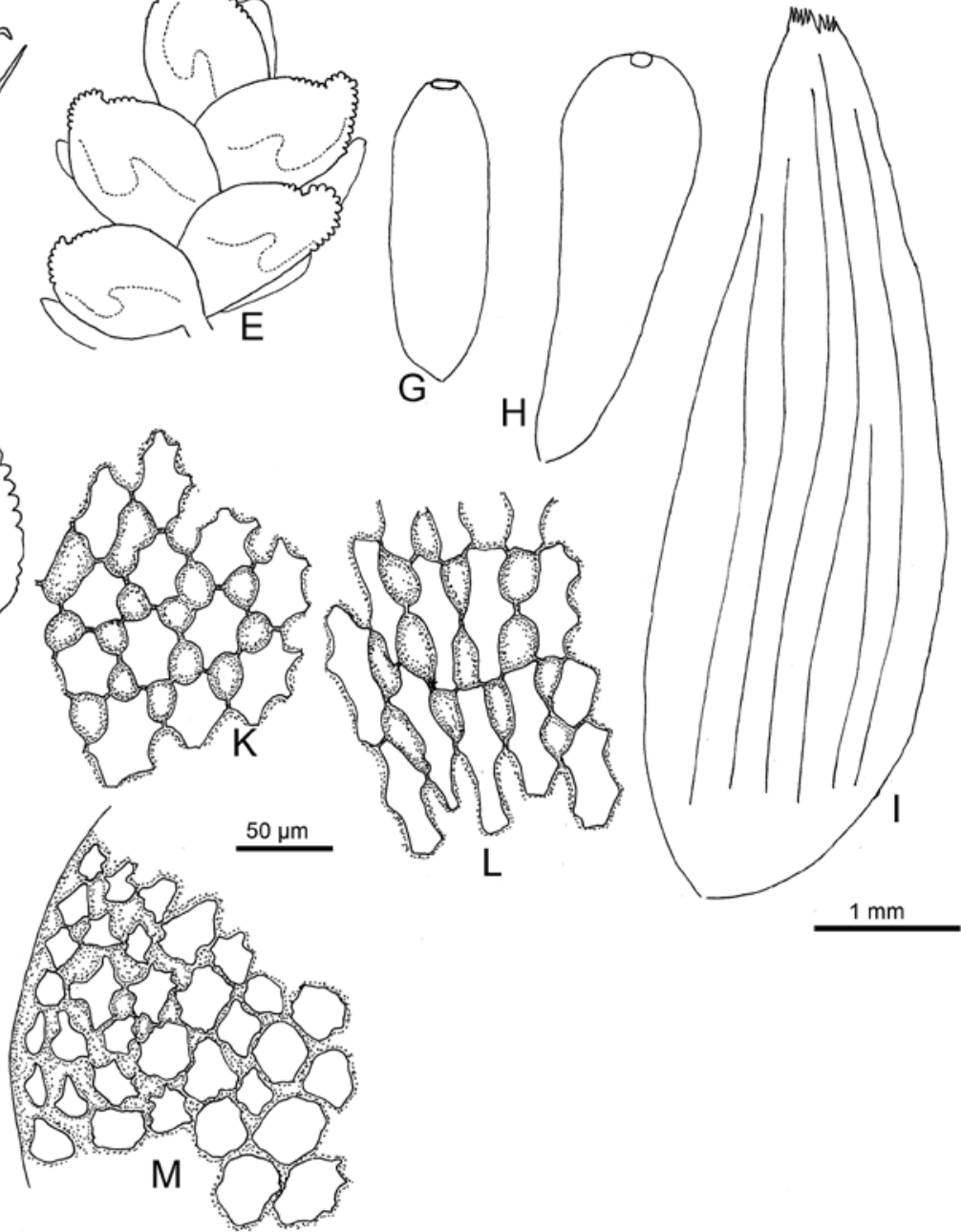

Fig. 1. Pleurozia pocsii Frank Müll., sp. nov. A \& B - explanate-lobulate leaves, C - bract of fertile gynoecia, D - bract of sterile gynoecia, E - branch with saccate-lobuled leaves, dorsal view, F - saccate-lobulate leaf, ventral view, G \& H - sterile perianths, I - fertile perianth, $\mathrm{K}$ - leaf cells of leaf apex, $\mathrm{L}$ - leaf cells near leaf base, $\mathrm{M}$ - part of stem cross section. Scale bars: A-E - 0,5 mm, F - $200 \mu \mathrm{m}, \mathrm{G}-\mathrm{I}-1 \mathrm{~mm}, \mathrm{~K}-\mathrm{M}-50 \mu \mathrm{m}$. All figures from Müller NC708 (holotype). 

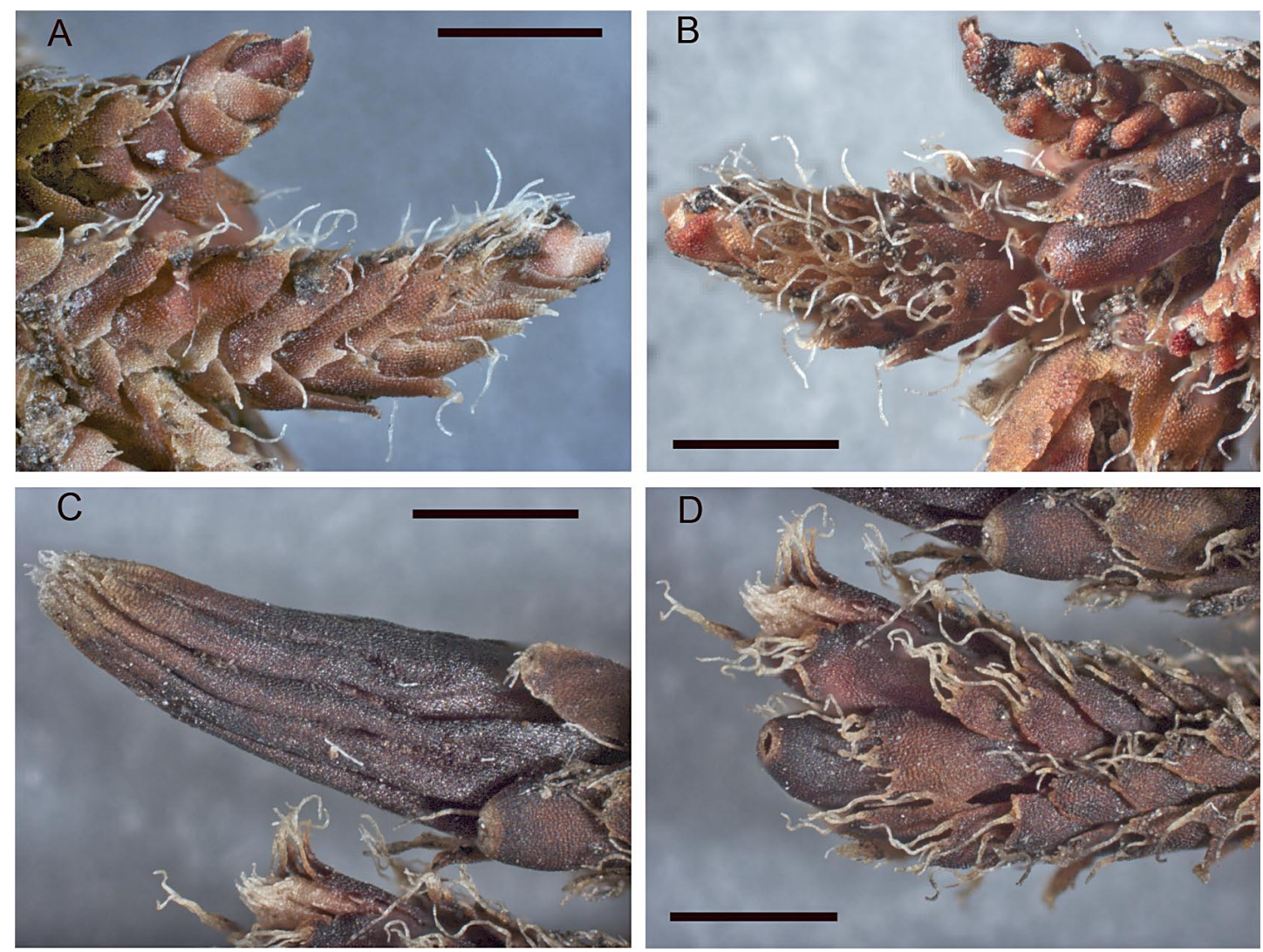

Fig. 2. Pleurozia pocsii Frank Müll., sp. nov. A - branches with explanate-lobuled leaves, B - branches with sterile gynoecia and sterile perianths (centre right) and branches with saccate-lobuled leaves (top right), $\mathrm{C}$ - fertile gynoecia with a fertile perianth, D - branches with sterile gynoecia and sterile perianths. Scale bars: $1 \mathrm{~mm}$. All figures from Müller NC708 (holotype).

\section{DISCUSSION}

The new species belongs in subgenus Diversifolia B. M. Thiers, a subgenus characterized by saccate lobules of the acinosa-type, explanate lobules, clustered sterile gynoecia and, in fertile gynoecia, the bract lobes extending $0.25-0.50$ the length of the bract.

Pleurozia pocsii is very distinctive in its characters, especially in the laciniate dorsal and ventral leaf lobe apices of the explanate-lobuled leaves, a unique feature in Pleurozia. Whereas the bracts of the fertile gynoecia are laciniate in some species of the genus (e.g., P. caledonica, $P$. heterophylla and $P$. gigantea), in $P$. pocsii in addition the bracts of the sterile gynoecia are laciniate, another unique feature in Pleurozia. Also characteristic of $P$. pocsii are the strongly bulging cells at the apex of dorsal lobules of the saccatelobuled leaves.

ACKNOWLEDGEMENTS. I'm grateful to Michael Kallmeyer of the University of Dresden for help in preparation of the photographs, and to Martin J. Wigginton (Warmington) for checking the English and helpful remarks.

\section{REFERENCES}

Crandall-Stotler B. 1976. The apical cell and early development of Pleurozia purpurea Lindb. Lindbergia 3: 198-208.

Crandall-Stotler B., Stotler R. E. \& Long D. G. 2009. Phylogeny and Classification of the Marchantiophyta. Edinburgh J. Bot. 66: 155-198. 
He-Nygrén X., Juslén A., AhONEN I., GLENNY D. \& PIIPPO S. 2006. Illuminating the evolutionary history of liverworts (Marchantiophyta) - towards a natural classification. Cladistics 22: 1-31.
ThIERs B. M. 1993. A monograph of Pleurozia (Hepaticae; Pleuroziaceae). Bryologist 96: 517-554.

Received 23 January 2013 